\title{
Effects of Local Greenhouse Gas Abatement Strategies on Air Pollutant Emissions and on Health in Kuopio, Finland
}

\author{
Arja Asikainen ${ }^{1, *}$, Erkki Pärjälä ${ }^{2}$, Matti Jantunen ${ }^{3}$, Jouni T. Tuomisto ${ }^{1}$ and Clive E. Sabel ${ }^{4}$ \\ National Institute for Health and Welfare, Kuopio 70210, Finland; jouni.tuomisto@thl.fi \\ City of Kuopio, Environmental Protection Services, Kuopio 70110, Finland; erkki.parjala@kuopio.fi \\ Emeritus in National Institute for Health and Welfare, Kuopio 70210, Finland; matti.jantunen@janding.fi \\ 4 Department of Environmental Sciences, Aarhus University, Roskilde 4000, Denmark; cs@envs.au.dk \\ * Correspondence: arja.asikainen@thl.fi; Tel.: +358-29-534-6469
}

Academic Editors: Sotiris Vardoulakis and Jennifer Salmond

Received: 18 May 2017; Accepted: 16 June 2017; Published: 19 June 2017

\begin{abstract}
Implementation of greenhouse gas (GHG) abatement strategies often ends up as the responsibility of municipal action rather than national policies. Impacts of local GHG reduction measures were investigated in the EU FP7 funded project Urban Reduction of Greenhouse Gas Emissions in China and Europe (URGENCHE). Kuopio in Finland was one of the case study cities. The assessed reduction measures were (1) increased use of biomass in local heat and power cogeneration plant, (2) energy efficiency improvements of residences, (3) increased biofuel use in traffic, and (4) increased small scale combustion of wood for residential heating. Impact assessment compared the 2010 baseline with a $2020 \mathrm{BAU}$ (business as usual) scenario and a $2020 \mathrm{CO}_{2}$ interventions scenario. Changes in emissions were assessed for $\mathrm{CO}_{2}$, particulate matter $\left(\mathrm{PM}_{2.5}\right.$ and $\left.\mathrm{PM}_{10}\right), \mathrm{NO}_{\mathrm{x}}$, and $\mathrm{SO}_{2}$, and respective impacts were assessed for $\mathrm{PM}_{2.5}$ ambient concentrations and health effects. The assessed measures would reduce the local $\mathrm{CO}_{2}$ emissions in the Kuopio urban area by over $50 \%$ and local emissions of $\mathrm{PM}_{2.5}$ would clearly decrease. However, the annual average ambient $\mathrm{PM}_{2.5}$ concentration would decrease by just $4 \%$. Thus, only marginal population level health benefits would be achieved with these assumed local $\mathrm{CO}_{2}$ abatement actions.
\end{abstract}

Keywords: air pollution; climate change mitigation; local health effects; $\mathrm{CO}_{2}$ emissions

\section{Introduction}

Greenhouse gas (GHG) emissions influence the ecosystems globally, and a great amount of effort, both economical and human resources, has been and will be invested to limit these influences. The most important GHGs are carbon dioxide $\left(\mathrm{CO}_{2}\right)$, nitrogen oxides $(\mathrm{NOx})$, methane $\left(\mathrm{CH}_{4}\right)$, ozone $\left(\mathrm{O}_{3}\right)$, hydrofluorocarbons (HFCs), and perfluorocarbons (PFCs). The first four occur naturally as well as being man-made, and the two others exist only as man-made products. The main human activities that produce these gases are fuel combustion, energy production, transportation, industry, various manufacturing processes, and agriculture. Effects associated to GHG emissions are spatiotemporal changes in climate that further influence rainfall, sea levels, extreme weather conditions, biodiversity, agriculture, spread of diseases, etc. GHG inventories were previously performed in 1990 by IPCC [1]. To mitigate emissions, it is essential to understand the causal relations between emissions and the major activities producing them.

In recent decades, joint global political efforts to develop common abatement commitments for GHG emissions reduction have been actively on-going. Common protocols, such as the 1997 Kyoto Protocol and more recently the 2015 Paris Agreement, have led to national strategies and policies to 
limit emissions. In most cases, the final fine tuning and actual implementation of the policies is the responsibility of municipalities. This means that the local effects and timelines of implementation may vary a lot, both between and within countries [2].

Various policies focus on the use of alternative fuels and sources of energy, energy conservation, and land use modifications. Besides GHG-emissions, emissions of other pollutants may also be affected by these policies. These pollutants, such as particulate matter, harm human health, and the implementation of emissions reducing policies can bring health benefits $[3,4]$. When assessing and comparing the planned or executed GHG abatement policies, it is informative to also estimate their local co-benefits instead of assessing only direct costs of the measures and their impacts on GHG emissions [5,6].

The assessment of the local short term co-benefits of urban scale implementation of GHG-mitigation policies on public health and well-being was the objective of the EU FP7 funded project Urban Reduction in Greenhouse Gas Emissions in China and Europe (URGENCHE) [7]. This assessment was targeted on five case study cities in Europe and two in China. This article presents results of the assessment for the city of Kuopio in Finland with the following objectives: (1) evaluate how local greenhouse gas abatement strategies affect air pollutant emissions, (2) assess the local health effects of fine particulate matter $\left(\mathrm{PM}_{2.5}\right)$ in Kuopio, and (3) analyze spatial differences in the exposures to $\mathrm{PM}_{2.5}$ (i.e., particles with an aerodynamic diameter of 2.5 micrometers or less).

\section{Materials and Methods}

\subsection{Study Area}

Kuopio is an inland city, $400 \mathrm{~km}$ N-NE from Helsinki, in Finland. The surroundings of Kuopio are mainly covered by woods and water, and the landscape is hilly (90 to $210 \mathrm{~m}$ above sea level). The main $15 \mathrm{~km} \times 10 \mathrm{~km}$ urban area of Kuopio was the study area. In 2010, this area covered $62 \%$ of the residential buildings ( $53 \%$ of the detached houses, $96 \%$ of the attached houses, and $99 \%$ of the high rise apartment buildings) and $87 \%$ (around 81,000 ) of the population in the whole, much larger $\left(3700 \mathrm{~km}^{2}\right)$ Kuopio municipality. Currently the local economy is mainly based on public and private services, education and research, and industry. Kuopio is considered as a technological and business center of the region with some major industrial plants, like a cardboard factory and a large combined heat and power plant (Haapaniemi CHP-plant). In 2010, over 75\% of the residences and almost all of the non-residential buildings in the urban area were heated by district heat produced by the two units of the wood chips, peat, and biogas fired heat (capacity $300 \mathrm{MW}$ ) and power (120 MW) cogenerating plant. Both units apply fluidized bed combustion technology, which makes them flexible for different fuels. The rest of the residences were heated with electricity (13\%), heating oil (5\%), wood (3\%), and geothermal heat (1\%).

\subsection{Greenhouse Gas Emission}

Heating buildings (district heat, electricity, separate heating) contributed $42 \%$ of the total $\mathrm{CO}_{2 \text {-eq }}$ (i.e., green house gas emissions equivalent to $\mathrm{CO}_{2}$ warming potential) emission of 1020 kilotons in 2010 (Figure 1) ([8] only in Finnish).

\subsection{Abatement Strategies and Scenarios}

The city of Kuopio aims to reduce its total GHG emissions by $40 \%$ by 2020 compared to 1990 . This target is presented in Kuopio's climate strategy for the years 2009-2020, which was used as a guideline for the $\mathrm{CO}_{2}$ emission intervention scenarios assessed in this study. The selected scenarios were built to be realistic so that they could produce useful information about the impacts of the Kuopio's climate policy programme. To ensure this, several departments of the city (traffic and town planning, land use, the energy company, and the department of environmental protection) were involved in defining the intervention policies to be assessed. 


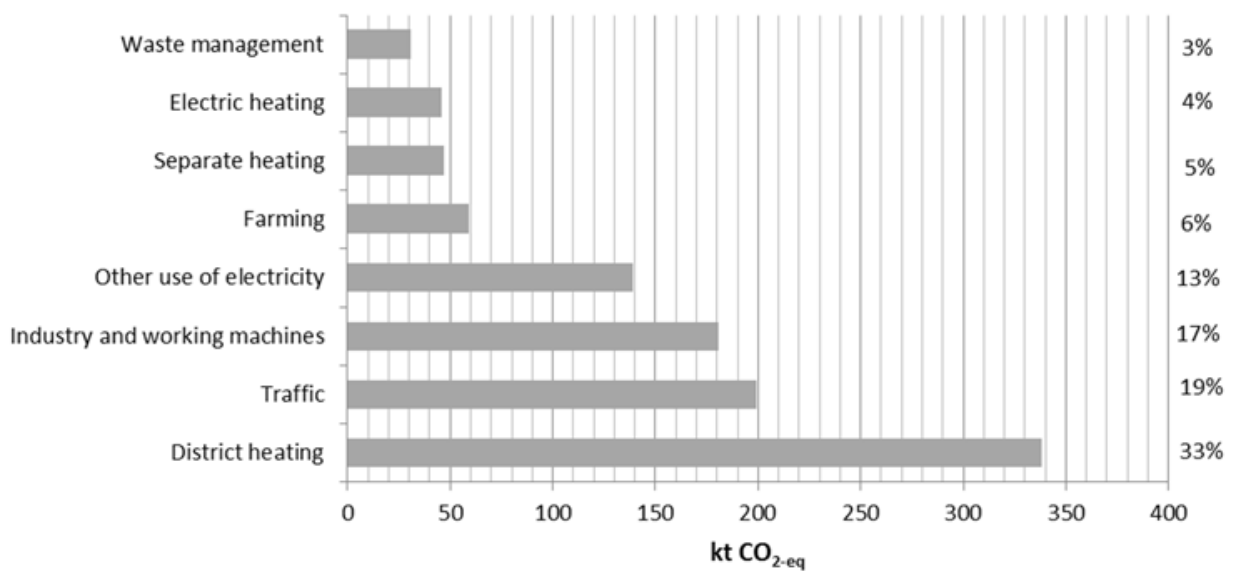

Figure 1. Amount of $\mathrm{CO}_{2}$ emissions (kilotonnes $\mathrm{CO}_{2-\mathrm{eq}}$ ) by emission sector in the Kuopio area in 2010.

The scenarios focused mainly on the increased use of biomass/biofuels in heat and power generation and traffic and the improved energy efficiency of buildings, i.e., the main national policies for GHG emission reduction in Finland. The selected supply side actions were (1a) increased use of biomass in the local Haapaniemi combined heat and power plant (CHP-plant) and (1b) increased use of wood in small scale combustion, and demand side actions (2a) improved insulation of renovated and new buildings and (3a) increased use of biofuels in traffic (estimated as "lower emitting" cars due to the absence of real emission factors for liquid biofuels). Assessments were based on comparison of the 2010 baseline as the current situation with the 2020 business as usual (BAU) scenario and the 2020 $\mathrm{CO}_{2}$ intervention scenario describing the impacts of the selected actions (Table 1).

Table 1. Assumptions for each scenario and description of the changed factors.

\begin{tabular}{|c|c|c|c|}
\hline Action & 2010 Baseline & 2020 BAU & $2020 \mathrm{CO}_{2}$ Interventions \\
\hline \multirow{2}{*}{$\begin{array}{l}\text { (1a) Increased use of } \\
\text { biomass in the } \\
\text { Haapaniemi CHP-plant }\end{array}$} & $* 4 \%$ biomass & $* 4 \%$ biomass & $* 50 \%$ biomass \\
\hline & $\begin{array}{l}\text { * Total generation as in } \\
2010 \text { (a) }\end{array}$ & $\begin{array}{l}\text { * Total generation based on } \\
\text { estimated need for } 2020 \text { (d) }\end{array}$ & $\begin{array}{l}\text { * Total generation based on } \\
\text { estimated need for } 2020 \text { (d) }\end{array}$ \\
\hline \multirow{2}{*}{$\begin{array}{l}\text { (1b) Increased use of } \\
\text { wood for residential } \\
\text { heating }\end{array}$} & \multirow{2}{*}{$\begin{array}{l}\text { * Sources of heat as in } \\
\qquad 2010^{(b)}\end{array}$} & \multirow{2}{*}{$\begin{array}{l}\text { * Share of each source for } \\
\text { heat as in } 2010^{(b)}\end{array}$} & $\begin{array}{l}\text { * Oil heating replaced with } \\
\text { small scale wood burning }\end{array}$ \\
\hline & & & $\begin{array}{c}\text { * Double the use of wood for } \\
\text { supporting heating } \\
\text { compared to } 2010\end{array}$ \\
\hline \multirow{2}{*}{$\begin{array}{l}\text { (2a) Increased use of } \\
\text { biofuels in traffic }\end{array}$} & $* 5 \%$ biofuels & $* 20 \%$ biofuels & $* 30 \%$ biofuels \\
\hline & $\begin{array}{l}\text { * Volume of used fuel as } \\
\text { in } 2010 \text { (c) }\end{array}$ & $\begin{array}{l}\text { * Volume of used fuels based } \\
\text { on traffic volume increase }(\mathrm{e})\end{array}$ & $\begin{array}{l}\text { * Volume of used fuels based } \\
\text { on traffic volume increase (e) }\end{array}$ \\
\hline \multirow{2}{*}{$\begin{array}{l}\text { (3a) Improved energy } \\
\text { efficiency of residences }\end{array}$} & \multirow{2}{*}{$\begin{array}{l}\text { * Average annual heating } \\
\text { need } 166 \mathrm{kWh} / \mathrm{m}^{2} / \mathrm{a} \\
\text { (based on district heat } \\
\text { usage in 2010) }\end{array}$} & $\begin{array}{c}* 3 \% \text { of residences renovated } \\
\text { annually }(2010-2020)(\mathrm{f})\end{array}$ & $\begin{array}{c}* 3 \% \text { of residences renovated } \\
\text { annually }(2010-2020){ }^{(\mathrm{f})}\end{array}$ \\
\hline & & $\begin{array}{c}* \text { Annual heating need } \\
70 \mathrm{kWh} / \mathrm{m}^{2} / \mathrm{a} \text { in renovated } \\
\text { and new buildings }\end{array}$ & $\begin{array}{c}* \text { Annual heating need } \\
25 \mathrm{kWh} / \mathrm{m}^{2} / \mathrm{a} \text { in renovated } \\
\text { and new buildings }\end{array}$ \\
\hline
\end{tabular}

(a) data from the local CHP-plant, personal communication, ${ }^{(b)} \mathrm{CO}_{2}$ report ([8], only in Finnish) ${ }^{\text {(c) }}$ from a traffic model LIISA 2011 ([9], only in Finnish) ${ }^{\text {(d) }}$ estimated based on the predictions by municipality (personal communication), and predictions on floor area growth ([10], only in Finnish) ${ }^{(e)}$ estimations from traffic model LIISA 2011 ([9], only in Finnish) and from estimated increase of vehicle-kms ([11], only in Finnish) ${ }^{(\mathrm{f})}$ predicted renovation rate ([10], only in Finnish). 


\subsection{Scenario Data}

Comprehensive data for the assessments was collected from various reports, databases, and statistics. For the 2010 baseline, the actual data was used, and for 2020, different predictions for upcoming trends were applied (Table 2).

Table 2. Input data in each scenario.

\begin{tabular}{lccc}
\hline \multicolumn{1}{c}{ Data } & 2010 Baseline & 2020 BAU & 2020 Interventions \\
\hline Population & $80,425^{(\mathrm{a})}$ & $85,940^{(\mathrm{f})}$ & $*$ \\
Residences, total floor area & $4,480,857^{(\mathrm{b})}$ & $4,729,032^{(\mathrm{g})}$ & $*$ \\
- Residences, renovated, floor area $\left(\mathrm{m}^{2}\right)$ & & $1,308,905^{(\mathrm{h})}$ & $*$ \\
- Residences, new, floor area $\left(\mathrm{m}^{2}\right)$ & & $248175^{(\mathrm{g})}$ & $*$ \\
$\quad$ - Residences, not renovated, floor area $\left(\mathrm{m}^{2}\right)$ & $4,480,857$ & $3,171,952$ & $*$ \\
Residences, annual average heating need & $165.5^{(\mathrm{c})}$ & $165.5^{* *}$ & $165.5^{* *}$ \\
(kWh/m $/ \mathrm{a})_{\text {Residences, total heat demand (GWh/a) }}$ & $742^{(\mathrm{d})}$ & $75^{* * *}$ & $25.0^{* * *}$ \\
- District heat & 580 & $634^{(\mathrm{i})}$ & $564^{(\mathrm{i})}$ \\
- Oil & 35 & 496 & 441 \\
- Electricity & 98 & 30 & 0 \\
- Geothermal & 8 & 84 & 75 \\
- Wood & 21 & 7 & 6 \\
Total use of fuels in the Haapaniemi power plant & $1709^{(\mathrm{c})}$ & $1536^{(\mathrm{i})}$ & 42 \\
(GWh) & $514^{(\mathrm{e})}$ & $555^{(\mathrm{j})}$ & $1277^{(\mathrm{i})}$ \\
Traffic mileage (million km/a) & $38,135^{(\mathrm{e})}$ & $41186^{(\mathrm{k})}$ & $*$ \\
Total use of traffic fuels (tons/a) & 22500 & 24300 & $*$ \\
- Diesel & 15635 & 16886 & $*$ \\
- Petrol & & & $*$ \\
\hline
\end{tabular}

\footnotetext{
(a) actual population data from city authorities, personal communication, ${ }^{(b)}$ actual floor area from building registry, personal communication, (c) data from the local CHP-plant, personal communication, ${ }^{(d)}$ based on the average heating need and sources of heating methods from $\mathrm{CO}_{2}$ report ([8], only in Finnish) and from a questionnaire (unpublished data), (e) from a traffic model LIISA 2011 ([9], only in Finnish), (f) predictions by municipality (personal communication), (g) estimated based on the predictions by municipality (personal communication), and predictions on floor area growth ([10], only in Finnsih) ${ }^{(h)}$ based on predicted renovation rate ([10], only in Finnish) ${ }^{(i)}$ estimated, ${ }^{(j)}$ estimated increase of vehicle-kms ([11], only in Finnish) ${ }^{(\mathrm{k})}$ estimations from traffic model LIISA 2011 ([9], only in Finnish) and from estimated increase of vehicle-kms ([11], only in Finnish). * Same data as for the 2020 BAU scenario, ${ }^{* *}$ Data for old, and ${ }^{* * *}$ for new and renovated residences
}

\subsection{Population and Residences}

Population growth was predicted by the city administration based on the current plans for buildings construction and economic development in the region.

For the year 2010, the actual residential floor area in Kuopio urban area was retrieved from the building registry. The prediction for the year 2020 was based on the assumption that the residential floor area will grow in proportion with the population growth, i.e., $45 \mathrm{~m}^{2} /$ new inhabitant. In addition, $3 \%$ of the existing floor area was assumed to be renovated annually between 2010 and 2020. This trend was estimated by Technical Research Centre of Finland (VTT) and based on the age distribution of the national building stock and renovation data from the most recent decades ([10], only in Finnish).

\subsection{Heat Demand and Production}

The baseline total residential heat demand was based on the actual 2010 district heat data (representing $78 \%$ of the total) available from the local supplier (personal communication). For the 2020 scenarios residential heat demand prediction was based on two assumptions: (1) for the 2020 BAU scenario it was assumed that new and renovated buildings will consume $70 \mathrm{kWh} / \mathrm{m}^{2} / \mathrm{a}$ (the requirement for new buildings by the Finnish building code in year 2010), and (2) for the $2020 \mathrm{CO}_{2}$ interventions scenario, the new and renovated buildings were assumed to be nearly zero energy buildings of $25 \mathrm{kWh} / \mathrm{m}^{2} / \mathrm{a}$ in an average year. All current non-renovated buildings were assumed to 
keep on consuming the same amount of energy as in 2010. Building stock data for the predictions was retrieved from the Finnish building registry with a personal query through municipality authorities.

The realism of these assumptions is supported by the developments of the past three decades when the heat demand of the whole Finnish building stock has decreased by almost $50 \%$ and in buildings connected to the district heat, by $30 \%$ ([10], only in Finnish).

The share of each source of heat in 2010 is based on the annual national $\mathrm{CO}_{2}$ report, which collects data on energy generation, consumption, and traffic, and also provides regional $\mathrm{CO}_{2}$ emission estimates ([8], only in Finnish). However, the estimation in this report includes the whole municipal area of Kuopio, so we refined the information based on a survey investigating the actual share of each source of heat for the urban area. For the 2020 BAU scenario, the respective shares of the different sources of heat were assumed to be the same as in the 2010 baseline, but in the $2020 \mathrm{CO}_{2}$ interventions scenario, oil was assumed to be replaced by small-scale wood combustion.

The 2010 baseline district heat generation in the Haapaniemi CHP-plant was based on the consumption and production data retrieved from the energy company (Kuopio Energy Group, personal communication). In $2010,84 \%$ of the used fuel was peat, $12 \%$ oil, and $4 \%$ biomass (wood). For the 2020 scenarios, the estimated fuel use in the CHP-plant was based on the predicted changes in the volume and heat demand of the building stock. The proportions of fuels used in the $2020 \mathrm{BAU}$ scenario were assumed to be the same as in the 2010 baseline and in the $2020 \mathrm{CO}_{2}$ interventions scenario: $50 \%$ peat and $50 \%$ wood chips.

\subsection{Traffic}

The actual road network and the traffic volumes used for the 2010 baseline emission estimation. VTT has developed the software to calculate traffic exhaust emissions for municipalities, provinces and the whole of Finland, and the car fleet information for Kuopio was available in the "Road traffic exhaust emissions calculation model" module (LIISA, version 2011 used) ([9], only in Finnish). The road network in 2020 was estimated based on the assumed increase of the population and the current plans for the road network.

The 2010 proportions of diesel (59\%) and petrol (41\%) ([9], only in Finnish) were assumed to stay the same in 2020. The total consumption of fuels was assumed to increase $8 \%$ from 2010 to 2020 based on two estimations: (1) LIISA 2011 system estimates that the use of fuels in Finland increases 8.9\% during this time, and (2) it has been estimated for the Kuopio area that the vehicle-kms will increase by $16 \%$ from 2011 to 2030 ([11], only in Finnish), and linear increase would mean an increase of $8 \%$ from 2010 to 2020. In the 2010 baseline $5 \%$ of the consumed fuels was biofuels. The effect of biofuels on the $\mathrm{CO}_{2}$ emissions was based on the estimations in the LIISA 2011 system.

There was no reliable data available to estimate particulate matter emissions for fuels with the different proportions of biofuels. In the 2010 baseline, the particulate matter emissions were assumed to correspond to EURO3 emission class. In the 2020 BAU scenario, emissions were based on EURO4, and in the $2020 \mathrm{CO}_{2}$ interventions scenario, on EURO5. These EURO-classifications [12] were used to reflect the upcoming changes in the car fleet and the restrictions for emission of particulate matter.

\subsection{Health Effects}

Because $\mathrm{CO}_{2}$ does not have direct health effects, impact of the studied intervention actions on health were estimated by assessing changes in the ambient concentrations of fine particulate matter, which have been linked to increased cardiopulmonary mortality and various other acute and chronic health end-points, such as aggravation of asthma, respiratory symptoms, and an increase in hospital admissions $[13,14]$. Health effects were estimated by using exposure-risk functions, i.e., in this case relative risk (RR) and unit risk (UR), derived by epidemiological studies [15-17]. In cases with RR functions, a population attributable fraction (PAF) was calculated to relate exposure to risk of health effects (Equation (1)).

$$
\mathrm{PAF}=\mathrm{f} \times\left(\mathrm{RR}^{\circ}-1\right) / \mathrm{f} \times\left(\mathrm{RR}^{\circ}-1\right)+1,
$$


where $\mathrm{f}$ is the fraction of population exposed (in this case 1 ). $\mathrm{RR}^{\circ}=$ relative risk with the prevailing exposure level. The number of attributable cases is calculated by multiplying PAF with the background incidence data, which in this case was available through the national databases and statistics.

If based on the UR estimates, the attributable incidence (AI) of a particular health effects is (Equation (2)),

$$
\mathrm{AI}=\mathrm{E} \times \mathrm{UR} \times \mathrm{P}
$$

where $\mathrm{E}$ is the population exposure concentration, UR the unit risk, and $\mathrm{P}$ the size of the exposed population.

The background incidence data, ERFs, and calculated PAFs for the health impact assessment are presented in the Table 3.

Table 3. Data for the health impact calculations.

\begin{tabular}{|c|c|c|c|}
\hline Health End Point & Background Incidence & $\operatorname{ERF}^{(a)}$ & PAF $^{(b)}$ \\
\hline Mortality (all cause) & $732^{\text {(c) }}$ & $\begin{array}{c}1.006 \\
(1.004-1.008)(\mathrm{g})\end{array}$ & $\begin{array}{c}0.04 \\
(0.03-0.05)\end{array}$ \\
\hline Restricted activity days (RADs) & $\begin{array}{l}2.1 \text { million in whole Finland } \\
\text { due to } \mathrm{PM}_{2.5} \text { exposure }\end{array}$ & $\begin{array}{c}0.09 \\
(0.08-0.10) \\
\text { (h) }\end{array}$ & \\
\hline $\begin{array}{c}\text { Chronic bronchitis ( }>27 \mathrm{yr}, \\
\text { new cases) }\end{array}$ & $230^{(\mathrm{d})}$ & $\begin{array}{c}5.3 \times 10^{-5} \\
\left(1.7 \times 10^{-6}-1.1 \times 10^{-4}\right)(h)\end{array}$ & $\begin{array}{c}0.13 \\
(0.004-0.27)\end{array}$ \\
\hline $\begin{array}{c}\text { Cardiovascular hospital } \\
\text { admissions }\end{array}$ & 2109 (e) & $\begin{array}{c}1.001 \\
(1.000-1.002)\end{array}$ & $\begin{array}{c}0.01 \\
(0.00-0.01)\end{array}$ \\
\hline Respiratory hospital admissions & $1150^{(\mathrm{f})}$ & $\begin{array}{c}1.002 \\
(1.000-1.004)\end{array}$ & $\begin{array}{c}0.01 \\
(0.00-0.03)\end{array}$ \\
\hline
\end{tabular}

(a) $\mathrm{ERF}=$ Exposure response function per $1 \mu \mathrm{g} / \mathrm{m}^{3}$, central estimates with $95 \%$ confidence intervals in parentheses: unit risk (UR) for chronic bronchitis and restricted activity days, relative risk (RR) for others, ${ }^{(b)}$ PAF $=$ population attributable fraction, central estimates with 95\% confidence intervals in parentheses (c) Sotkanet.fi; In Kuopio area 910.7 cases /100,000 inhabitants [18], (d) Kelasto-database; disease class 203, includes asthma cases too [19], (e) 2735.1/100,000 inhabitants inpatient cases for cardiovascular diseases in year 2010 in whole Finland [20], (f) Total of 1413.2/100 000 inhabitants inpatient cases for respiratory disease in year 2010 in whole Finland [20], (g) Hoek et al., 2013 [15], (h) Hurley et al., 2005 [16], (i) Heroux et al., 2015 [17].

\subsection{Modelling Emissions and Dispersion}

$\mathrm{CO}_{2}$ emissions were calculated for each scenario by using the data in the Table 2 and the emission factors in the Table 4.

Table 4. Fossil $\mathrm{CO}_{2}$ emission factors for different sources of heat and for fuels.

\begin{tabular}{|c|c|c|c|}
\hline Fuel or Heating Source & 2010 Baseline & 2020 BAU & $2020 \mathrm{CO}_{2}$ Interventions \\
\hline District heat $(\mathrm{g} / \mathrm{kWh})^{(\mathrm{a})}$ & 305 & 305 & 164 \\
\hline Oil $(\mathrm{g} / \mathrm{kWh})^{(\mathrm{b})}$ & 267 & 267 & 267 \\
\hline Electricity $(\mathrm{g} / \mathrm{kWh})^{(\mathrm{b})}$ & 200 & 200 & 200 \\
\hline Geothermal heat $(\mathrm{g} / \mathrm{kWh})^{(\mathrm{b})}$ & 200 & 200 & 200 \\
\hline Peat $(\mathrm{g} / \mathrm{kWh})^{(\mathrm{b})}$ & 381 & 381 & 381 \\
\hline Wood and biomass $(\mathrm{g} / \mathrm{kWh})$ (c) & 0 & 0 & 0 \\
\hline Diesel (g/L) ${ }^{(\mathrm{d})}$ & $2548 *$ & $2101^{* *}$ & $1825^{* * *}$ \\
\hline Gasoline (g/L) ${ }^{(d)}$ & $2209 *$ & $1701^{* *}$ & $1422 * * *$ \\
\hline
\end{tabular}

(a) Based on the actual production and used fractions of peat, oil and biomass at the Haapaniemi CHP-plant. (b) Motiva Oy, national estimates in year 2010 ([21], only in Finnish). (c) Motiva Oy, national estimates in year 2010 ([21], only in Finnish). $\mathrm{CO}_{2}$ released during wood burning is assumed to be re-taken by plants with zero net effect. See Discussion for further considerations. (d) Based on the LIISA modelling system ([9], only in Finnish) data on emissions with the different fraction of biofuels, ${ }^{*}=5 \%$ of biofuels, ${ }^{* *}=20 \%$ of biofuels, ${ }^{* * *}=30 \%$ of biofuels. Here, the net effect of biofuel is assumed zero. See Discussion.

The emission and dispersion modelling of $\mathrm{PM}_{2.5}, \mathrm{PM}_{10}$ (i.e., particles with an aerodynamic diameter of 10 micrometers or less), $\mathrm{EC}$ (elemental carbon), and $\mathrm{NO}_{2}$ from traffic, Haapaniemi 
CHP-plant, and small scale combustion done by the Finnish meteorological institute (FMI) ([22], only in Finnish) were used to estimate the emissions in our scenarios. Results modelled for year 2005 were used to represent the baseline 2010 scenario, and for the $2020 \mathrm{BAU}$ and the $\mathrm{CO}_{2}$ intervention scenarios, some adjustment were made for FMI results to fit them to our scenarios. Traffic results were used directly, as FMI modelled the future scenarios with the assumptions of our scenarios, but concentrations from the Haapaniemi CHP-plant and separate heating in the 2020 scenarios were scaled by our estimated heating needs and estimated amounts and type of used fuels.

For point sources, i.e., for the Haapaniemi CHP-plant and small scale combustion, an Urban Dispersion Modelling system (UDM-FMI) was used [23]. For traffic sources, a line source model "Contaminants in the Air from a Road" (CAR-FMI) [24,25] was used. For point sources, the emissions of each source (based on the used amount of fuel), features of the flue gases, technical data of the facility, and the duration of operation were taken into account. For traffic emissions, the vehicle fleet and hourly changes of its use, proportion of different vehicle types, traffic speed, and emission factors based on the vehicle type were included, and the emissions were calculated as time series with hourly emissions for each pollutant.

For the traffic originated $\mathrm{PM}_{10}$ also suspension from the streets was modeled with a suspension model [26], based on the particle emission model developed by the Swedish meteorological institute (SMHI) [27]. The used $\mathrm{PM}_{10}$ emission factors were $200 \mu \mathrm{g} /$ vehicle $/ \mathrm{m}$ in summer and $1200 \mu \mathrm{g} /$ vehicle $/ \mathrm{m}$ in winter. The model calculates the suspension from the road surface based on the moisture of the street, wind, rain, use of spiked tires and use of sand during slippery days. The final suspension is calculated with the same line source model as the other traffic emissions (CAR-FMI). The model does not take into account salting of roads and possible methods for the dust binding.

Meteorological data used in the dispersion model calculations was based on three-year monitoring data. The weather data was obtained from three representative weather stations to create the final meteorological data provided as hourly time series.

Total emissions were calculated per year and concentrations were calculated for point grid with 7453 points. The distance between the points varies from 50 to $500 \mathrm{~m}$ being smaller in the vicinity of important sources and around roads. This GIS-coded data allowed us to calculate the spatial differences in the concentrations and in the exposures for the postal code areas.

\section{Results}

\subsection{Pollutant Emissions}

The total annual $\mathrm{PM}_{2.5}$ emissions decrease from 103 to 81 tons ( $\left.-22 \%\right)$ between the 2010 baseline and the $2020 \mathrm{BAU}$, and to 51 tons in the $2020 \mathrm{CO}_{2}$ interventions scenario (Figure 2a). The decrease of $51 \%$ is caused mostly by the reduced emissions from the Haapaniemi CHP-plant and to a lesser extent from traffic. $\mathrm{PM}_{2.5}$ emissions from the local sources could be heavily decreased in the Kuopio urban area by increasing the use of biomass in the Haapaniemi CHP-plant and a lower emitting car fleet. However, the $\mathrm{PM}_{2.5}$ emissions from small scale combustion more than double compared to the 2010 baseline, because of the assumed increased use of small scale wood combustion in the $2020 \mathrm{CO}_{2}$ intervention scenario.

The total $\mathrm{PM}_{10}$ emissions behave differently compared to the emissions of $\mathrm{PM}_{2.5}$. The total $\mathrm{PM}_{10}$ emissions actually increase between the 2010 Baseline and the 2020 BAU scenarios from 262 to 274 tons/year (Figure 2b). Reason for this is the higher traffic volumes causing more suspended $\mathrm{PM}_{10}$ emissions from the road surface. However, $\mathrm{PM}_{10}$ emissions from the Haapaniemi CHP-plant and traffic tailpipe decrease, so an overall a decrease of $11 \%$ is achieved from the 2010 baseline to the $2020 \mathrm{CO}_{2}$ interventions scenario.

The total $\mathrm{NOx}$ and $\mathrm{SO}_{2}$ emissions were available only for the Haapaniemi CHP-plant. The actions assumed in the $\mathrm{CO}_{2}$ interventions scenario, but also the other upcoming emission limits and the technical improvements, which have also been taken into account in this estimation, clearly decrease 
the emissions of $\mathrm{NOx}$ (by $65 \%$ ) and $\mathrm{SO}_{2}$ (by 79\%) from the 2010 baseline to the $2020 \mathrm{CO}_{2}$ interventions scenario (Figure 2c).

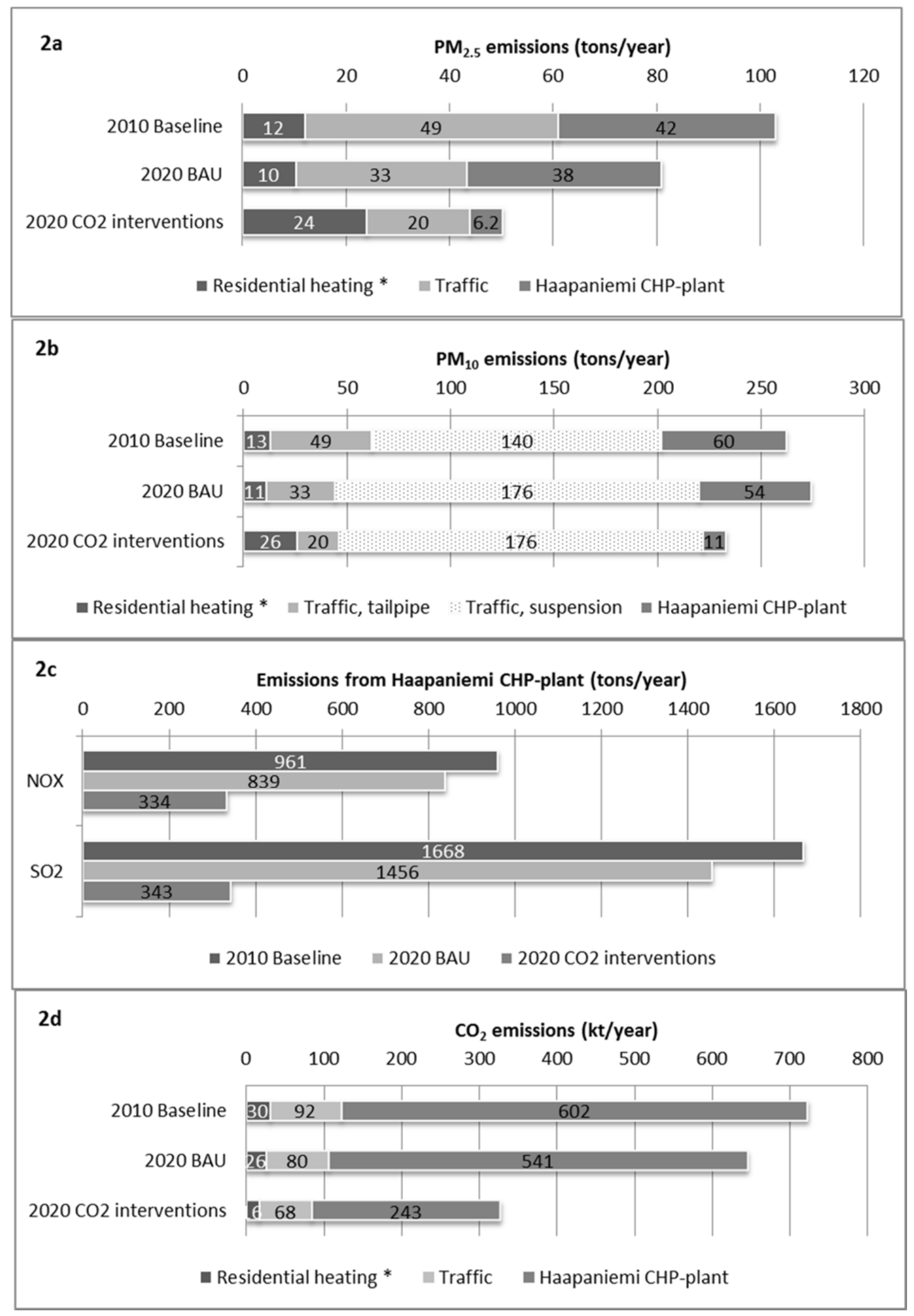

Figure 2. Emissions of (2a) $\mathrm{PM}_{2.5}$, (2b) $\mathrm{PM}_{10},(2 \mathbf{c}) \mathrm{NOx}$ and $\mathrm{SO}_{2}$ and (2d) $\mathrm{CO}_{2}$ from the assessed sources in each scenario. * Residential heating without district heat. 
$\mathrm{CO}_{2}$ emissions decrease from the 2010 baseline to the 2020 BAU scenario by $15 \%$ and to the 2020 $\mathrm{CO}_{2}$ interventions scenario by $55 \%$ (Figure $2 \mathrm{~d}$ ). The decrease is mainly explained by the reduced emissions from the Haapaniemi CHP-plant, due to the replacement of peat partly by wood chips and the decreased heat demand of the more energy efficient building stock.

\subsection{Local Concentrations and Exposures}

The highest annual concentrations of $\mathrm{PM}_{2.5}$ from traffic occur, as expected, near the thruway and the main streets leading to the city center, and in the city center. In the 2010 baseline scenario, maximal annual concentration of $\mathrm{PM}_{2.5}$ originating from traffic, $4.0 \mu \mathrm{g} / \mathrm{m}^{3}$, is found around the southern highway exit leading toward the city center. The lowest annual average traffic generated $\mathrm{PM}_{2.5}$ concentrations, below $0.5 \mu \mathrm{g} / \mathrm{m}^{3}$, are observed in the southern suburbs, where the distance to the thruway is several kilometers. $\mathrm{PM}_{2.5}$ contribution from traffic is clearly decreased by the 2020 intervention scenario, and the highest annual concentration is now $1.8 \mu \mathrm{g} / \mathrm{m}^{3}$.

Contribution of the Haapaniemi CHP-plant to the local annual average $\mathrm{PM}_{2.5}$ concentrations remains very low (maximum $0.014 \mu \mathrm{g} / \mathrm{m}^{3}$ ) even at the 2010 baseline. This was anticipated because the plant is equipped with state-of-the-art fly ash collectors and its high stacks dilute and disperse the emissions beyond the local urban airspace.

Small scale wood combustion exhibits clear spatial differences in its contribution to the annual average $\mathrm{PM}_{2.5}$ concentrations. This is caused by the differences of the main sources of heat between the different areas in Kuopio. There are some areas with older detached houses that are not connected to the district heating system. However, the highest annual average concentration from small scale combustion in the 2010 baseline still remains only $0.6 \mu \mathrm{g} / \mathrm{m}^{3}$. This clearly indicates that traffic is the major local source of the annual $\mathrm{PM}_{2.5}$ levels in the urban area of Kuopio.

For the health impact estimation, the total ambient annual average concentration of $\mathrm{PM}_{2.5}$ was needed. Long range transportation is the main source of $\mathrm{PM}_{2.5}$ for the Kuopio region. Its contribution was estimated by subtracting the FMI modelled GIS-mapped annual average concentrations (year 2005) from the measured $\mathrm{PM}_{2.5}$ concentration (year 2010) in one urban air quality measurement station (Kasarmipuisto). This indicates an annual average background concentration of $6.1 \mu \mathrm{g} / \mathrm{m}^{3}$, in line with a recent FMI estimation ([28], only in Finnish).

The assessed sources contributed $12 \%$ to the total ambient annual average level of $\mathrm{PM}_{2.5}$ in the 2010 baseline (Table 5). This decreased to $8 \%$ in the $2020 \mathrm{CO}_{2}$ interventions scenario, a decrease of $0.3 \mu \mathrm{g} / \mathrm{m}^{3}$.

Table 5. Annual average concentrations of $\mathrm{PM}_{2.5}\left(\mu \mathrm{g} / \mathrm{m}^{3}\right)$.

\begin{tabular}{cccc}
\hline Source & 2010 Baseline & 2020 BAU & 2020 CO $_{\mathbf{2}}$ Interventions \\
\hline Traffic & 0.5 & 0.4 & 0.2 \\
Haapaniemi CHP-plant & 0.0 & 0.0 & 0.0 \\
Small scale combustion & 0.3 & 0.2 & 0.3 \\
Total * & 6.9 & 6.7 & 6.6 \\
\% of intervention sources & $12 \%$ & $9 \%$ & $8 \%$ \\
\hline
\end{tabular}

${ }^{*}$ Includes background of $6.1 \mu \mathrm{g} / \mathrm{m}^{3}$.

In general, this evaluation demonstrates that in Kuopio, the ambient annual average levels of $\mathrm{PM}_{2.5}$ are affected only slightly by the local sources ( $7 \%$ from traffic, $0.0 \%$ from the Haapaniemi CHP-plant, and $4 \%$ from small scale combustion). Consequently, although the described local decisions can reduce the annual $\mathrm{PM}_{2.5}$ emissions by 52 tons, they can only marginally reduce the $\mathrm{PM}_{2.5}$ exposures within the urban area. On the other hand, actions in Kuopio will reduce the $\mathrm{PM}_{2.5}$ concentrations in a much larger area around the city. 


\subsection{Health Effects}

The estimated health impacts of the $\mathrm{PM}_{2.5}$ exposure in Kuopio urban area are quite low in the 2010 baseline scenario, and because the ambient $\mathrm{PM}_{2.5}$ levels are only marginally affected in the 2020 intervention scenarios, the health impacts remained essentially unchanged (Table 6).

Table 6. The health impacts of $\mathrm{PM}_{2.5}$ exposure in population of Kuopio urban area as number of cases. Central estimates with $95 \%$ confidence intervals in parentheses.

\begin{tabular}{|c|c|c|c|}
\hline Health End Point & 2010 Baseline & 2020 BAU & $2020 \mathrm{CO}_{2}$ Interventions \\
\hline Mortality (all cause) & $29(19-38)$ & $28(19-37)$ & $28(19-37)$ \\
\hline Restricted activity days (RADs) & $\begin{array}{c}49,787 \\
(43,716-55,749)\end{array}$ & $\begin{array}{c}48,682 \\
(42,745-54,511)\end{array}$ & $48,354(42,457-54,143)$ \\
\hline Chronic bronchitis ( $>27 \mathrm{yr}$, new cases) & $29(1-62)$ & $29(1-61)$ & $29(1-61)$ \\
\hline Cardiovascular hospital admissions & $14(3-25)$ & $13(3-24)$ & $13(2-24)$ \\
\hline Respiratory hospital admissions & $15(-1-30)$ & $14(-1-30)$ & $14(-1-29)$ \\
\hline
\end{tabular}

The wide ranges in the estimates for chronic bronchitis and cardiovascular and respiratory hospital admissions are caused by the uncertainties in the respective exposure response functions.

\subsection{Socio-Demographic Differences}

Originally, we aimed to evaluate whether the health impacts were distributed evenly within the Kuopio population. However, as the overall health impacts were so low that the spatial analysis was done only for the annual average ambient $\mathrm{PM}_{2.5}$ levels.

Based on the GIS mapped concentration data, the annual average ambient $\mathrm{PM}_{2.5}$ levels varied between suburbs (defined by postal codes) in Kuopio from 6.5 to $7.8 \mu \mathrm{g} / \mathrm{m}^{3}$. These were related to the social indicators of $\%$ unemployed, $\%$ foreigners, $\%>63$ year olds, annual average income, $\%$ population having a higher education and \% population with bad credentials. Two of these indicators- $\%$ of $>63$ year olds (Figure 3a) and annual average income (Figure 3b)-showed some relation with the $\mathrm{PM}_{2.5}$ concentrations.
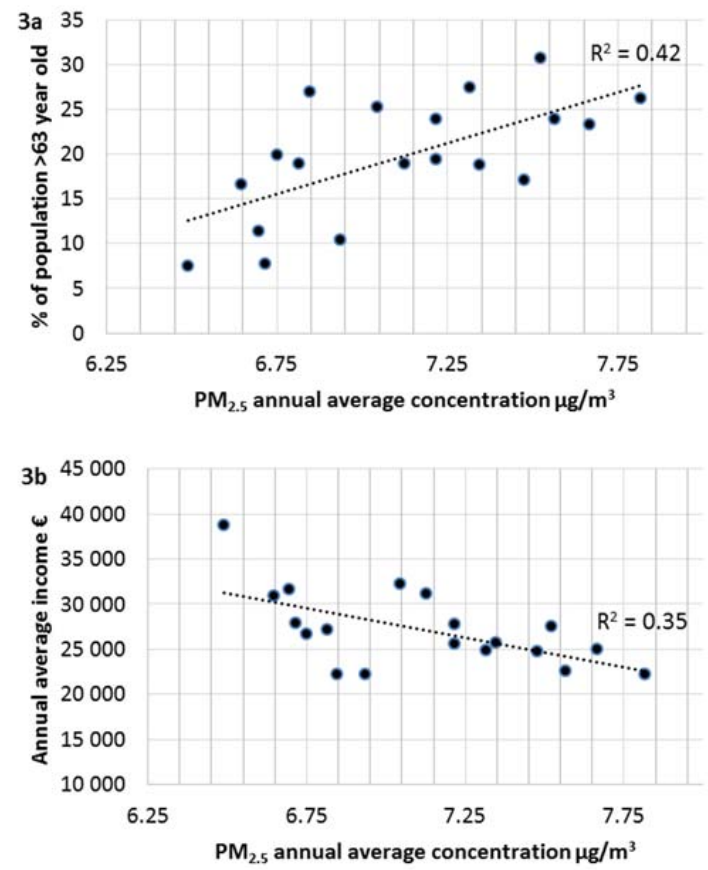

Figure 3. GIS mapped $\mathrm{PM}_{2.5}$ annual average concentrations in urban Kuopio postal code areas related to $(3 \mathbf{a}) \%$ of population $>63$ year olds and to $(3 \mathbf{b})$ annual average income. 
It seems that older people and people with low income live in areas with the higher $\mathrm{PM}_{2.5}$ annual average levels. This makes sense as a high proportion of older people in Kuopio live close to the city center, where the $\mathrm{PM}_{2.5}$ levels are the highest because of the traffic. On the other hand, some of the suburbs with the oldest apartment buildings with cheaper rents are located near the highway. This trend between low socioeconomic status (SES) and higher exposures to air pollutants is in line with previous studies from other geographical locations [29-32].

\section{Discussion}

Increased use of biofuels in traffic and in heat and power generation is a cornerstone of the national GHG abatement strategies in Finland and prioritized locally in the Kuopio area. The assessment demonstrates that actions can have a major effect on the local fossil $\mathrm{CO}_{2}$ emissions, in this case lowering them by $55 \%$ from the 2010 baseline to the $2020 \mathrm{CO}_{2}$ interventions scenario.

However, GHG $\mathrm{CO}_{2}$ from the combustion of fossil fuels is identical to $\mathrm{CO}_{2}$ from biofuels, which have been assumed to exhibit zero net $\mathrm{CO}_{2}$ emission, because the $\mathrm{CO}_{2}$ released into the atmosphere in the combustion has originally been absorbed from the atmosphere. Since 2008 [33,34] a growing amount of literature has argued that this assumption simplifies too much by ignoring the energy consumption in biofuels production and in particular the emissions from forest clearing for wood biomass harvesting and the farming of biofuel crops. Realistic net GHG impacts of biofuel use depend on the time horizon, the alternatives compared to, biomaterials used, production methods, etc., and vary from zero to higher than the fossil alternative. In spite of the many regulations that assume zero net emission, it is clear that this assumption does not reflect reality.

IPCC, however, advises the use of national emission factors in cases where they are available [35]. We therefore used the emission factors provided by the national expert organization Motiva Oy, which recommended in 2010 the use of zero as the emission factor for wood and wood residues. If the re-take circulation is ignored instead (which errors in the opposite direction), the $\mathrm{CO}_{2}$ emission factor of wood products $(109.6 \mathrm{t} / \mathrm{TJ})$ is actually a bit higher than for peat (97-107 t/TJ), oil (73.5 t/TJ), and coal (93.3 t/TJ) [36].

Local measures can clearly effect the local emissions, but the effect on the total ambient concentrations of pollutants may end up being small. This is the case in areas where most of the total pollution load is caused by long range transport. $\mathrm{PM}_{2.5}$ is a good example of this kind of a pollutant, and to tackle this issue, common and joint continent-wide efforts are needed to improve air quality on the larger scale.

In this case, traffic was the largest contributor of the local sources to the ambient annual levels of $\mathrm{PM}_{2.5}$. As there were no $\mathrm{PM}_{2.5}$ emission factors available for different biofuels, no realistic assumptions could be made for the 2020 scenarios. More importantly, several other studies have demonstrated that much higher health benefits can be achieved by GHG abatement strategies that reduce emissions by replacing motor vehicle transportation with biking and walking [37-40].

The increased use of small scale wood combustion was estimated to have a small effect on the total $\mathrm{CO}_{2}$ emissions in the Kuopio urban area. However, its contribution to the annual average ambient $\mathrm{PM}_{2.5}$ level from local sources was estimated to increase by $26 \%$. Its short term neighborhood impacts are likely to be higher because small scale combustion sources are located at rooftop levels in the residential areas and are typically in use at times when neighbors are at home. In addition, they are a source of polycyclic aromatic compounds, which have carcinogenic effects. Smoke of small-scale wood burning can also cause negative effects on wellbeing, which was indicated by a survey done for the residents in the urban area of Kuopio [41]. Based on these conclusions, increased use of wood in small scale combustion cannot be recommended as an action to reduce $\mathrm{CO}_{2}$ emissions in populated urban areas.

This study was done in close co-operation with the city organization, policy makers, and the research institute. This joint collaboration showed that there is a need to provide tools for cities and municipalities to make local health impact assessments of local policies and measures. This is 
now being considered in Index Air, a recently started project in which the city of Kuopio is one of the stakeholders and a representative of the possible end-users of the management tool, which is planned to be used to evaluate effects of the local measures affecting on air pollution and on health in municipality level.

\section{Conclusions}

The assessed GHG abatement measures have a noticeable effect on the total emissions of air pollutants in the Kuopio urban area. The increased use of biomass in the Haapaniemi power plant is a recommended measure to reduce fossil $\mathrm{CO}_{2}$ emission in the study area. The increased small scale combustion of wood increases emissions of particulate matter and has at best a minor decreasing effect on $\mathrm{CO}_{2}$ emissions, so it cannot be recommended as an action to tackle GHG emissions. In this case, the assessed $\mathrm{CO}_{2}$ reduction measures have a minor effect on the average local annual ambient $\mathrm{PM}_{2.5}$ levels as the main contributor is long-range transport. Because of this, health benefits of the assessed measures were low. In the Kuopio area, elderly people and people with lower income seem to live in areas where levels of particulate matter are higher.

Acknowledgments: This work was supported by the European 7th Framework Programme (FP7) project: Urban Reduction of GHG Emissions in China and Europe (URGENCHE: Grant Agreement No. 265114).

Author Contributions: Arja Asikainen, Erkki Pärjälä, Matti Jantunen, Jouni T. Tuomisto, and Clive E. Sabel conceived and designed the study. Arja Asikainen and Erkki Pärjälä collected the local data. Arja Asikainen performed the calculations, and analyzed the data with the help of Jouni T. Tuomisto. Arja Asikainen wrote the paper with the help and contributions of Erkki Pärjälä, Matti Jantunen, Jouni T. Tuomisto, and Clive E. Sabel.

Conflicts of Interest: The authors declare no conflict of interest.

\section{References}

1. IPCC. Climate Change: The IPCC Scientific Assessment; Houghton, J.T., Jenkins, G.J., Ephraums, J.J., Eds.; Cambridge University Press: Cambridge, UK; New York, NY, USA, 1990.

2. Gupta, J. The multi-level governance challenge of climate change. Environ. Sci. 2007, 4, 131-137. [CrossRef]

3. Haines, A.; McMichael, A.J.; Smith, K.R.; Roberts, I.; Woodcock, J.; Markandya, A.; Armstrong, B.G.; Campbell-Lendrum, D.; Dangour, A.D.; Davies, M.; et al. Public health benefits of strategies to reduce greenhouse-gas emissions: overview and implications for policy makers. Lancet 2009, 374, 2104-2114. [CrossRef]

4. Cifuentes, L.; Borja-Aburto, V.H.; Gouveia, N.; Thurston, G.; Davis, D.L. Hidden Health Benefits of Greenhouse Gas Mitigation. Science 2001, 293, 1257-1259. [CrossRef] [PubMed]

5. Nemet, G.F.; Holloway, T.; Meier, P. Implications of incorporating air quality co-benefits into climate change policymaking. Environ. Res. Lett. 2010, 5, 014007. [CrossRef]

6. Pittel, K.; Rübbelke, D.T.G. Climate policy and ancillary benefits: A survey and integration into the modelling of international negotiations on climate change. Ecolog Econom 2008, 68, 210-220. [CrossRef]

7. Sabel, C.E.; Hiscock, R.; Asikainen, A.; Bi, J.; Depledge, M.; van den Elshout, S.; Freiedrich, R.; Huang, G.; Hurley, F.; Jantunen, M.; et al. Public Health impacts of city policies to reduce climate change: findings from the URGENCHE EU-China project. Environ. Health 2016, 15, 5-21. [CrossRef] [PubMed]

8. Benviroc Oy. Kuopion Kasvihuonekaasupäästöt 2006, 2008-2010; Benviroc Oy: Espoo, Finland, 2011.

9. LIPASTO-A Calculation System for Traffic Exhaust Emissions and Energy Use in Finland. VTT Technical Research Centre of Finland Ltd. LIISA Modelling System 2010. Road Traffic Exhaust Emissions Calculation Model module. Available online: http://www.lipasto.vtt.fi/en/liisa/index.htm (accessed on 2 February 2017).

10. Koskinen, A.-L.; Olkinuora, J.; Elo, J.; Perttula, S.; Ruotsalainen, A.; Sevander, V. Kuopion Kasvihuonekaasupäästöjen Vähentämismahdollisuudet v 2020 Mennessä; Raportti 16WWE0924; Pöyry Finland Oy: Vantaa, Finland, 2011.

11. Kalenoja, H.; Keränen, M. KUOMA-raportti. Kuopion alueen liikennemalli 2012. Tampereen teknillinen yliopisto. Liikenteen tutkimuskeskus Verne. Tutkimusraportti 80, Tampere Finland 2012. Available online: http://www.tut.fi/verne/wp-content/uploads/Kuoma_raportti2012_1009.pdf (accessed on 2 February 2017). 
12. Regulation (ec) No. $715 / 2007$ of the European parliament and of the council of 20 June 2007 on type approval of motor vehicles with respect to emissions from light pas senger and commercial vehicles (Euro 5 and Euro 6) and on access to vehicle repair and maintenance information. Official Journal of the European Union. 2007. Available online: http:/ / eur-lex.europa.eu/LexUriServ /LexUriServ.do?uri=OJ:L:2007:171:0001:0016: EN:PDF (accessed on 8 June 2017).

13. Anderson, J.O.; Thundiyil, J.G.; Stolbach, A. Clearing the Air: A Review of the Effects of Particulate Matter Air Pollution on Human Health. J. Med. Toxicol. 2012, 8, 166-175. [CrossRef] [PubMed]

14. Kim, K.-H.; Kabir, E.; Kabir, S. A review on the human health impact of airborne particulate matter. Environ. Int. 2015, 74, 136-143. [CrossRef] [PubMed]

15. Hoek, G.; Krishnan, R.M.; Beelen, R.; Peters, A.; Ostro, B.; Brunekreef, B.; Kaufman, J.D. Long-term air pollution exposure and cardio- respiratory mortality: A review. Environ. Health 2013, 12, 43. Available online: http:/ / www.ehjournal.net/content/12/1/43 (accessed on 7 February 2017).

16. Hurley, F.; Hunt, A.; Cowie, H.; Holland, M.; Miller, B.; Pye, S.; Watkiss, P. Methodology Paper (Volume 2) for Service Contract for carrying out cost-benefit analysis of air quality related issues, in particular in the clean air for Europe (CAFE) programme. AEAT/ED51014/Methodology Volume 2: Issue 2. AEA Technology Environment: United Kingdom, 2005. Available online: http://ec.europa.eu/environment/archives/cafe/ pdf/cba_methodology_vol2.pdf (accessed on 7 February 2017).

17. Héroux, M.E.; Anderson, H.R.; Atkinson, R.; Brunekreef, B.; Cohen, A.; Forastiere, F.; Hurley, F.; Katsouyanni, K.; Krewski, D.; Krzyzanowski, M.; et al. Quantifying the health impacts of ambient air pollutants: Recommendations of a WHO/Europe project. Int. J. Pub. Health 2015, 60, 619-627. [CrossRef]

18. Sotkanet.fi. Statistical information on welfare and health in Finland. Causes of death 2010 in Kuopio area. Available online: https:/ / www.sotkanet.fi/sotkanet/en (accessed on 7 February 2017).

19. Statistical database Kelasto. Existing, new and withdrawn entitlements to reimbursement of drug expenses. Available online: http:/ /www.kela.fi/web/en/statistical-database-kelasto (accessed on 7 February 2017).

20. Eurostat. Hospital discharges by diagnosis, in-patients, per 100000 inhabitants. Available online: http: / / ec.europa.eu/eurostat/web/products-datasets/-/hlth_co_disch2 (accessed on 8 February 2017).

21. Motiva Oy. $\mathrm{CO}_{2}$-Laskentaohje Energiankulutuksen Hiilidioksidipäästöjen Laskentaan. Available online: https:/ / www.motiva.fi/ratkaisut/energiankaytto_suomessa/co2-laskentaohje_energiankulutuksen_ hiilidioksidipaastojen_laskentaan (accessed on 8 February 2017).

22. Komppula, B.; Salmi, J.; Rasila, T.; Kauhaniemi, M.; Lovén, K. Biopolttoaineiden Käytön Lisäyksen Vaikutus Kuopion Ilmanlaatuun Vuonna 2020. Autoliikenteen, Haapaniemen Voimalaitoksen ja Kiinteistökohtaisen Lämmityksen Päästöjen Leviämismallinnus. Ilmatieteen Laitos_Ilmanlaadun Asiantuntijapalvelut: Helsinki Finland, 2013. Available online: http://expo.fmi.fi/aqes/public/Biopolttoaineiden_kayton_lisayksen_ vaikutus_Kuopion_ilmanlaatuun_vuonna_2020.pdf (accessed on 3 May 2017).

23. Karppinen, A. Meteorological Pre-Processing and Atmospheric Dispersion Modeling of Urban Air Quality and Applications in the Helsinki Metropolitan Area. Academic Dissertation, University of Helsinki, Helsinki Finland, 2001. Finnish Meteorological Institute, Contributions No. 33, Helsinki.

24. Härkönen, J.; Valkonen, E.; Kukkonen, J.; Rantakrans, E.; Lehtinen, K.; Karppinen, A.; Jalkanen, L. A Model for the Dispersion of Pollution from a Road Network; Finnish Meteorological Institute: Helsinki, Finland, Yliopistopaino, 1996.

25. Härkönen, J. Regulatory Dispersion Modelling of Traffic-Originated Pollution; University of Helsinki: Helsinki, Finland, 2002.

26. Kauhaniemi, M.; Kukkonen, J.; Härkönen, J.; Nikmo, J.; Kangas, L.; Omstedt, G.; Ketzel, M.; Kousa, A.; Haakana, M.; Karppinen, A. Evaluation of a road dust suspension model for predicting the concentrations of $\mathrm{PM}_{10}$ in street canyon in Helsinki. Atmos. Environ. 2011, 45, 3646-3654. [CrossRef]

27. Omstedt, G.; Bringrelt, B.; Johansson, C. A model for vehicle-induced nontailpipe emissions of particles along Swedish roads. Atmosph Environ. 2005, 39, 6088-6097. [CrossRef]

28. Alaviippola, B.; Pietarila, H. Ilmanlaadun arviointi Suomessa. Pienhiukkaset (PM2,5). Ilmatieteen laitos, Ilmanlaadun asiantuntijapalvelut. Available online: http://www.ilmanlaatu.fi/ilmansaasteet/julkaisu/ pdf/pienhiukkasten_alustava_arviointi_2011_2.pdf (accessed on 2 February 2017).

29. Fecht, D.; Fischer, P.; Fortunato, L.; Hoek, G.; de Hoogh, K.; Marra, M.; Kruize, H.; Vienneau, D.; Beelen, R.; Hansell, A. Associations between air pollution and socioeconomic characteristics, ethnicity and age profile of neighbourhoods in England and the Netherlands. Environ. Pollut. 2015, 198, 201-210. [CrossRef] [PubMed] 
30. Havard, S.; Zmirou-navier, D.; Schillinger, C.; Bard, D. Traffic-related air pollution and socioeconomic status. Epidemiology 2009, 20, 223-230. [CrossRef] [PubMed]

31. Brochu, P.J.; Yanosky, J.D.; Paciorek, C.J.; Schwartz, J.; Chen, J.T.; Herrick, R.F.; Suh, H.H. Particulate air pollution and socioeconomic position in rural and urban areas of the northeastern United States. Am. J. Public Health 2011, 101, S224-S230. [CrossRef] [PubMed]

32. Hajat, A.; Diez-Roux, A.V.; Adar, S.D.; Auchincloss, A.H.; Lovasi, G.S.; O’Neill, M.S.; Sheppard, L.; Kaufman, J.D. Air pollution and individual and neighborhood socioeconomic status: Evidence from the Multi-Ethnic Study of Atherosclerosis (MESA). Environ. Health Perspect. 2013, 121, 1325-1333. [CrossRef] [PubMed]

33. Fargione, J.; Hill, J.; Tilman, D.; Polasky, S.; Hawthorne, P. Land Clearing and the Biofuel Carbon Debt. Science 2008, 319, 1235-1238. [CrossRef] [PubMed]

34. Searchinger, T.; Heimlich, R.; Houghton, R.A.; Dong, F.; Elobeid, A.; Fabiosa, J.; Tokgoz, S.; Hayes, D.; $\mathrm{Yu}, \mathrm{T}$.-H. Use of U.S. Croplands for Biofuels Increases Greenhouse Gases through Emissions from Land-Use Change. Science 2008, 319, 1238-1240. [CrossRef] [PubMed]

35. Gómez, D.R.; Watterson, J.D.; Americano, B.B.; Ha, C.; Marland, G.; Matsika, E.; Namayanga, L.N.; Osman-Elasha, B.; Kalenga Saka, J.D.; Treanton, K. Stationary Combustion, Chapter 2, 2006 IPCC Guidelines for National Greenhouse Gas Inventories. Available online: http://www.ipcc-nggip.iges.or.jp/public/ 2006gl/pdf/2_Volume2/V2_2_Ch2_Stationary_Combustion.pdf (accessed on 2 February 2017).

36. Statistics Finland. Fuel Classification 2016. Available online: http:/ /www.stat.fi/tup/khkinv/khkaasut polttoaineluokitus.html (accessed on 9 February 2017).

37. Woodcock, J.; Edwards, P.; Tonne, C.; Armstrong, B.G.; Ashiru, O.; Banister, D.; Beevers, S.; Chalabi, Z.; Chowdhury, Z.; Cohen, A.; et al. Public health benefits of strategies to reduce greenhouse-gas emissions: Urban land transport. Lancet 2009, 374, 1930-1943. [CrossRef]

38. Woodcock, J.; Givoni, M.; Morgan, A.S. Health Impact Modelling of Active Travel Visions for England and Wales Using an Integrated Transport and Health Impact Modelling Tool (ITHIM). PLoS ONE 2013, 8, e51462. [CrossRef] [PubMed]

39. Rojas-Rueda, D.; de Nazelle, A.; Teixidó, O.; Nieuwenhuijsen, M.J. Replacing car trips by increasing bike and public transport in the greater Barcelona metropolitan area: A health impact assessment study. Environ. Int. 2012, 49, 100-109. [CrossRef] [PubMed]

40. Xia, T.; Nitschke, M.; Zhang, Y.; Shah, P.; Crabb, S.; Hansen, A. Traffic-related air pollution and health co-benefits of alternative transport in Adelaide, South Australia. Environ. Int. 2015, 74, 281-290. [CrossRef] [PubMed]

41. Hiscock, R.; Asikainen, A.; Tuomisto, J.; Jantunen, M.; Pärjälä, E.; Sabel, C.E. City scale climate change policies: Do they matter for wellbeing? Prevent. Med. Rep. 2017, 6, 265-270. [CrossRef] [PubMed] 